SOIL Discuss., doi:10.5194/soil-2016-14, 2016

Manuscript under review for journal SOIL

Published: 7 March 2016

(c) Author(s) 2016. CC-BY 3.0 License.

(c) (1)

\title{
Relation of aggregate stability and microbial diversity in an incubated sandy soil.
}

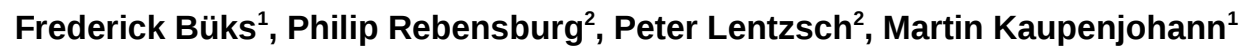

[1] Department of Ecology, Technische Universität Berlin, Germany

[2] Leibniz Center for Agricultural Landscape Research (ZALF e.V.), Müncheberg, Germany 


\section{Abstract}

Beside physico-chemical interactions between particulate organic matter (POM), mineral particles and dissolved molecules, microbial biofilms are an important factor of aggregate stability as a proxy of soil quality. Soil primary particles are linked by the highly viscous extracellular biofilm matrix known as extracellular polymeric substance (EPS). Matrix composition depends on the community of biofilm producing species and environmental conditions affecting gene expression.

This work investigates the influence of microbial biodiversity on soil aggregate stability under controlled environmental conditions. We hypothesized that the formation of different microbial populations would cause different aggregate stabilities. Therefor a sterile sandy agricultural soil with pyrochar amendment from pine wood was incubated for 76 days in pF-bioreactors. One variant was inoculated with a soil extract, whereas the other one was infected by airborne microbes. A control soil remained unincubated. During the incubation, soil samples were taken for taxon-specific qPCR to determine the abundance of eubacteria, fungi, archaea, acidobacteria, actinobacteria, $\alpha$-proteobacteria and $\beta$ proteobacteria. After incubation soil aggregates were separated for aggregate stability measurement by ultrasonication, density fractionation and SOC analysis.

As the eubacterial populations of both incubated variants reach a similar level after 49 days, the variant inoculated with the living soil extract shows a much higher fungal population compared to the air-born variant. Within the eubacterial population acidobacteria and $\beta$-proteobacteria differ significantly in their abundance between the variants. Although the variants show a strongly significant difference in eubacterial/fungal population structure, there are only marginal differences in aggregate stability. 


\section{Introduction}

Slipping on stones on a river bank, complaining about mucus of a severe cold, marveling about colorful microbial mats in volcanic hot springs and being pleased about the efficiency of biological waste water treatment - we are faced to the wide abundance of biofilms (Costerton et al., 1995). Biofilm formation on surfaces by excretion of extracellular polymeric substance (EPS) is an adaptation behavior of microbial life to manifold environmental stressors (Roberson and Firestone, 1992; Mah and O'Toole, 2001; Weitere et al., 2005; Chang et al., 2007; Ozturk and Aslim, 2010). Hence, in a world of unpleasant ecological conditions the bulk of global bacterial life is supposed to live in biofilms (Davey and O'toole, 2000). As shown in Büks and Kaupenjohann (in revision), surface-bound bacterial life can hold a 45 -fold higher bacterial abundance compared with the soil solution. That indicates a dominance of biofilms in soil bacterial communities.

Dependent on environmental conditions and biofilm building species, fresh biofilms have an average water content of $90 \%$ with extrema up to $97 \%$ (Zhang et al., 1998; Schmitt and Flemming, 1999; Pal and Paul, 2008). Only $10 \%$ to $50 \%$ of the remaining dry mass are microbial biomass, whereas the remaining matter mainly consists of extracellular macromolecules (More et al., 2014). These are extracellular polysaccharides, proteins, lipids and humic substances with a broad structural diversity within each substance class (Leigh and Coplin, 1992; Allison, 1998; Al-Halbouni et al., 2009; Ras et al., 2011) as well as extracellular DNA (eDNA) (Flemming and Wingender, 2010). Molecular masses of matrix polysaccharides between 13,700 and 2,000,000 Da suggest large strucutral diversity (Votselko et al., 1993).

Polysaccharides, eDNA, proteines and lipids have different functions affecting biofilm stability: Linked with polyvalent cations, polysaccharides and eDNA enhance the viscosity of EPS with increasing concentration and support cell aggregation and adhesion to surfaces (Das et al., 2014). Structural proteins bind extracellular polysaccharides, cell and inanimate surfaces. Also proteinous bacterial pili can take part in macromolecular entanglement. In addition, enzymes play a role in restructuring the biofilm matrix. Lipids on the other hand work as surfactants and support surface colonization and bioavailability of nutrients. (Flemming and Wingender, 2010) As a result of their mechanical strength (Möhle et al., 2007; Flemming and Wingender, 2010), structure (Van Loosdrecht et al., 2002) and their distribution across the soil aggregate structure (Nunan et al., 2003), biofilms are supposed to play a role in soil 
aggregate formation and stabilization (Baldock, 2002). Recent experiments gave evidence for this assumption (Büks and Kaupenjohann, in revision). In addition physico-chemical interactions between organic and mineral primary particles and dissolved molecules play a major role in soil aggregation (Bronick and Lal, 2005).

Although all biofilms contain extracellular polysaccharides, DNA (eDNA), proteins and lipids as structural agents (Flemming and Wingender, 2010), biofilm composition shows a broad variation. In different single-species biofilms cultivated with each identical media at the same incubation temperatures, specific EPS component compositions are strongly differing (Béjar et al., 1998; Steinberger and Holden, 2005; Celik et al., 2008). But also single-species biofilms of the same organism form EPS of different composition under varying environmental conditions as demonstrated for Pseudomonas aeruginosa (Marty et al., 1992; Ayala-Hernández et al., 2008). That points to a general dependency of EPS composition on species and environmental conditions.

Thus, it seems self-evident that complex multi-species biofilms differing in their phylogenetic diversity should also show a different composition of main biofilm components - however, experimental proof is still missing. Furthermore, this different EPS composition would generate differing mechanical EPS stability against tractive, compressive and shear forces, which is suggested by the findings of Ayala-Hernández et al. (2008).

Biofilm formation by soil microorganisms mainly appears as a reaction for protection against ecological stressors as e.g. grazing pressure, toxics and antibiotics, drought and radiation stress, but also act as genetic cross-over hotspot and collective digestive system for diverse soil nutrients (Flemming and Wingender, 2010). On the macro-scale, an environment moderately unpleasant for microorganisms drives biofilm formation and has positive effects on soil structure: High soil aggregate stability results in stable intraaggregate fine pores enhancing water retention, whereas the macropores between soil aggregates accelerate water transport, aeration, rootability and decrease erodability and compactability compared to a less aggregated soil (Bennie and Burger, 1988; Bengough and Mullins, 1990; Baumgartl and Horn, 1991; Taylor and Brar, 1991; Ball and Robertson, 1994; Barthes and Roose, 2002; Alaoui et al., 2011). In addition, soil aggregation has influence on carbon cycling as occluded particulate organic matter (POM) is protected against microbial degradation more effective than free POM (Six et al., 2002; Lützow et al., 2006). These features are identified as properties of fertile agricultural soils, and therefore aggregate stability can be seen as an integral proxy of soil quality. 
SOIL Discuss., doi:10.5194/soil-2016-14, 2016

Manuscript under review for journal SOIL

Published: 7 March 2016

(c) Author(s) 2016. CC-BY 3.0 License.

Although research about the microbial and biochemical composition and diversity of single- and multi-species biofilms exists and multiple functions of EPS components are well studied, the relation of microbial community composition and aggregate stability is still unknown. The aim of this work is to do a first step in this field by testing the influence of two fundamentally different microbial populations on the aggregate stability of a sandy agricultural soil. We hypothesized that after establishment of microbial populations different community structures will lead to different aggregate stabilities under further similar conditions. Therefore a gamma-sterilized sandy soil (Su3) with $5 \%$ pyrogene biochar amendment from pine wood was inoculated in two variants with microbial and sterile soil extract and incubated for 76 days in a pF-bioreactor under field capacity. Then abundances of eubacteria, fungi, archaea, acidobacteria, actinobacteria, $\alpha$ - and $\beta$ proteobacteria DNA were measured using taxon-specific $\mathrm{QPCR}$, and aggregate stability was determined by ultrasonication, density fractioning and carbon analytics.

A significant influence of the microbial populations structure on aggregate stability would confirm that conditions for microbial life should be considered in soil management practices. 


\section{Materials and Methods}

\subsection{Preparation of soil and soil extract}

Air-dried soil from a sandy A-horizon (Su3) of an agricultural experimental site in Berge (Germany) was sieved to $<2 \mathrm{~mm}$ and mechanically disaggregated in a mortar to receive an aggregate-free soil sample. The soil sample was amended with 5 vol\% of pyrogenic biochar (pine wood, PYREG ${ }^{\circledR} \mathrm{GmbH}$, Dörth/Germany) with a particle size $<0.1 \mathrm{~mm}$ and homogenized. Subsequently, the biochar soil was sterilized with $40.000 \mathrm{~Gy}$ using a Cobalt$60 \mathrm{y}$-radiation source and an exposure time of 2 weeks. The resulting soil had a pH of 7.1 in $0.01 \mathrm{M} \mathrm{CaCl}_{2}$ solution, $\mathrm{C}_{\text {org }}$ of $28.1 \mathrm{mg} \mathrm{g}^{-1}$ as well as an oven-dry density of $1.36 \mathrm{~g} \mathrm{~cm}^{-3}$ and a grain gross density of $2.54 \mathrm{~g} \mathrm{~cm}^{-3}$ resulting in a pore volume of $46.4 \%$.

To provide a soil-born microbial population, $1200 \mathrm{~g}$ of untreated fresh soil were extracted with $1560 \mathrm{ml}$ of 10-fold diluted modified R2A broth $\left(0.1 \mathrm{~g} \mathrm{l}^{-1} \mathrm{NH}_{4} \mathrm{NO}_{3}, 0.05 \mathrm{~g} \mathrm{l}^{-1}\right.$ yeast extract, $0.05 \mathrm{~g} \mathrm{l}^{-1}$ soy peptone, $0.05 \mathrm{~g} \mathrm{l}^{-1}$ casamino acids, $0.05 \mathrm{~g} \mathrm{l}^{-1}$ glucose, $0.05 \mathrm{~g} \mathrm{l}^{-1}$ soluble starch, $0.03 \mathrm{~g} \mathrm{l}^{-1} \mathrm{~K}_{2} \mathrm{HPO}_{4}, 0.0024 \mathrm{~g} \mathrm{l}^{-1} \mathrm{MgSO}_{4}, \mathrm{pH} 7.2 \pm 0.2$, autoclaved at $121^{\circ} \mathrm{C}$ for $20 \mathrm{~min}$ ) by end-over end shaking for 3 hours. The extract was filtered twice through two layers of laboratory tissue paper and afterwards split into two halves. One half was autoclaved at $120^{\circ} \mathrm{C}$ for 20 minutes, whereas the other half remain untreated.

\subsection{Incubation and sampling}

Under sterile conditions, each $300 \mathrm{~g}$ soil sample were filled into two triplicates of pFbioreactors diagrammed in Fig. 1. The reactors provide constant matrix potential and sterile air supply for microbial soil containment experiments. With a flow rate of $0.4 \mathrm{I} \mathrm{min}^{-1}$, the headspace was continually replaced by room air filtered with an $0.2 \mu \mathrm{m}$ membrane filter. The hydrostatic head was $120 \mathrm{~cm}$ and provided a soil water content of about $35.0 \mathrm{vol}$ $\%$ and a soil air content of 11.5 vol\% at pF 2.1 .

The first triplicate $\left(\mathrm{SP}_{\text {soil }}\right)$ was inoculated with $100 \mathrm{ml}$ of the untreated soil extract to reestablish the former microbial population, whereas the second triplicate got the sterilized inoculate to start as abiotic environment and be susceptible for infection by air-born microorganisms $\left(\mathrm{SP}_{\text {air }}\right)$. Soil extract exceeding the adjusted soil water content was removed by the hydrostatic head and discarded.

The soil columns were incubated for a total of 76 days at room temperature between columns were disconnected at day 24 and reconnected after add-on of $100 \mathrm{ml}$ of 10 -fold 
diluted modified R2A broth at day 50. This resulted in a stress factor setting including warm-humid conditions from day 1 to 24 , warm and drying-out conditions between day 25 and 50 as well as cold-humid conditions from day 51 to 76 , that is supposed to be promoting biofilm production.

Soil sampling for DNA analysis was performed using sterile plastic pipes. A $500 \mathrm{mg}$ composite sample at 3 evenly distributed sampling points was taken from each column 18 and 29 hours as well as 3, 5, 16, 49, 51 and 76 days after inoculation. The $\mathrm{SP}_{\text {soil }}$ samples were taken in the cleanbench, whereas $\mathrm{SP}_{\text {air }}$ was exposed to the unsterile room atmosphere for 15 min during sampling to enforce contamination. The samples were filled in $2 \mathrm{ml}$ reaction tubes and stored at $-20^{\circ} \mathrm{C}$ for later DNA extraction and quantification.

After day 76, soil parallels were removed from reactors and air-dried for 2 weeks in a laminar flow hood. A pH of 6.8 was measured for all variants. Afterwards soil aggregates of a size 0.63 to $2.0 \mathrm{~mm}$ were separated and used for analysis of aggregate stability.

\subsection{DNA extraction and qPCR}

DNA was extracted from $370 \mathrm{mg}$ dry soil equivalent using a NucleoSpin $\circledast$ Soil Kit (MACHEREY-NAGEL GmbH \& Co. KG, Düren/Germany) following the manual instructions. DNA sample purity, represented by $260 / 280 \mathrm{~nm}$ extinction ratio, was determined with a NanoDrop1000 spectrophotometer (NanoDrop Products, Wilmington, DE, USA) and assessed as free of contamination.

For quantification of different phylogenetic classes (acidobacteria, actinobacteria, $\alpha$ - and $\beta$ proteobacteria) and domains (archaea, eubacteria, fungi), a quantitative real-time PCR with specific primer pairs (Table 1) was performed using a QuantStudio ${ }^{\mathrm{TM}} 12 \mathrm{~K}$ Flex RealTime PCR System (Life Technologies, Grand Island, NY/USA). The reaction mix per sample contained $4 \mu \mathrm{l}$ of 5 x HOT FIREPol ${ }^{\circledR}$ EvaGreen ${ }^{\circ}$ HRM Mix ROX (Solis Biodyne, Tartu/Estonia), each $0.25 \mu \mathrm{l}$ of the proper 10pM fwd and rev primer solution (biomers.net, Ulm, Germany; Table 2), $14.5 \mu \mathrm{l}$ of PCR $\mathrm{H}_{2} \mathrm{O}$ and $1 \mu \mathrm{l}$ of template DNA. Amplification of DNA templates was executed having an initial denaturation at $95^{\circ} \mathrm{C}$ for 15 min followed by 40 thermocycles consisting of a denaturation at $95^{\circ} \mathrm{C}$ for $15 \mathrm{~s}$, annealing for $20 \mathrm{~s}$ at primerspecific temperatures listed in Table 1 and elongation at $72^{\circ} \mathrm{C}$ for $30 \mathrm{~s}$. PCR was checked for consistency by melting curve analysis.

Extracted DNA from standard organisms named in Table 1 was used as DNA standard, whereas DNA of non-target organisms from soil samples in return functioned as negative control. Sample-DNA dilution ranged between 1:1 and 1:100. 


\subsection{Aggregate stability}

Soil aggregate stability was determined using successive ultrasonication and density fractionation, separation and $\mathrm{C} / \mathrm{N}$-analysis of the released and floated POM (Kaiser and Berhe, 2014). Therefore, in a first step, $75 \mathrm{ml}$ of $1.6 \mathrm{~g} \mathrm{~cm}^{-3}$ dense sodium polytungstate solution (SPT) were added to $15 \mathrm{~g}$ of air-dried $\mathrm{SP}_{\text {soil }}$ and $\mathrm{SP}_{\text {air }}$ soil samples. Also a third triplicate $\left(\mathrm{SP}_{\text {pure }}\right)$ - remained unincubated - was analyzed. After 30 min of SPT infiltration into the soil matrix, free light fraction (fLF) floating after centrifugation at 3,569 $\mathrm{G}$ for $26 \mathrm{~min}$ was separated by filtering the SPT solution through an $1.5 \mu \mathrm{m}$ pore size glass fibre filter. In a second step, the remaining soil was filled up to $75 \mathrm{ml}$ SPT solution, ultrasonicated with $50 \mathrm{~J} \mathrm{ml}^{-1}$ using an ultrasonication device (Branson@ Sonifier 250), centrifuged and floating occluded light fraction (oLF $F_{50}$ ) was separated. The energy output of the ultrasonication device was therefor determined by measuring the heating rate of water inside a dewar vessel (Schmidt et al., 1999). Again the SPT solution was filled up to $75 \mathrm{ml}$. The sample was treated with an additional energy of $450 \mathrm{~J} \mathrm{~m} \mathrm{l}^{-1}$ and centrifuged. Floated occluded light fraction $\left(\mathrm{oLF}_{500}\right)$ and heavy fraction (HF) were separated and all separated light fractions (LFs) and $\mathrm{HF}$ samples were frozen at $20^{\circ} \mathrm{C}$, lyophilized, ground, dried at $105^{\circ} \mathrm{C}$ and analysed for organic carbon concentration using an Elementar Vario EL III CNS Analyzer. For comparison with natural-born soil aggregates, data of a soil sample $\left(A_{\text {pure }}\right)$ mainly containing aggregates of a size between 0.63 and $2.0 \mathrm{~mm}$ with a $\mathrm{pH}_{\mathrm{CaCl} 2}$ of $6.9, \mathrm{C}_{\text {org }}$ of 8.7 $\mathrm{mg} \mathrm{g}^{-1}$, a carbonate concentration of $0.2 \mathrm{mg} \mathrm{g}^{-1}$ and a $C_{\text {mic }}$ of $352 \mu \mathrm{g} \mathrm{g}^{-1}$ were included (Büks and Kaupenjohann, in revision). This soil has the same origin as SP soil samples.

\subsection{Statistics}

Statistic analysis of DNA data comprised calculation of mean values, standard deviations and analysis of variance. For each sampling date class-, domain- and total DNA concentrations of $\mathrm{SP}_{\text {soil }}$ and $\mathrm{SP}_{\text {air }}$ parallels were tested for significant difference using a two-sample t-test. Therefore each variant was tested with Shapiro Wilk test and Levene test to provide normal distribution and evidence of variance homogeneity. Similarly, LF carbon releases of $\mathrm{SP}_{\text {soil }}, \mathrm{SP}_{\text {air, }}, \mathrm{SP}_{\text {pure }}$ and $\mathrm{A}_{\text {pure }}$ were analyzed. In addition, a Tukey test was applied. 


\subsection{Microbial population analysis}

The DNA extracted from soil samples shows qualitative differences in the composition of eubacterial populations and furthermore quantitative differences in the fungal population between $\mathrm{SP}_{\text {soil }}$ and $\mathrm{SP}_{\text {air. }}$ It is expressed as ng DNA per mg dry soil $\left(\mathrm{ng} \mathrm{mg}^{-1}\right)$ and includes intra- and extracellular DNA. (Fig. 1)

Total eubacterial population is equal in both variants between day 49 and 76: Through day

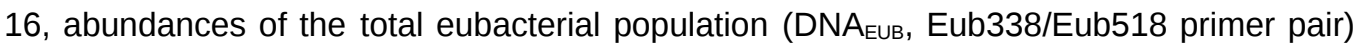
of $\mathrm{SP}_{\text {soil }}$ and $\mathrm{SP}_{\text {air }}$ differ significantly from each other $(\mathrm{p}<0.05)$ : As the amount of eubacterial DNA in $\mathrm{SP}_{\text {soil }}$ increases continuously from $1.28 \mathrm{ng} \mathrm{mg}^{-1}$ at trial beginning to $16.27 \mathrm{ng} \mathrm{mg}^{-1}$ at day 6 and subsequently decreases to $6.67 \mathrm{ng} \mathrm{mg}^{-1}$ at day 76, DNA of $\mathrm{SP}_{\text {air }}$ increases continuously from $0 \mathrm{ng} \mathrm{mg}^{-1}$ at day 0 to $13.58 \mathrm{ng} \mathrm{mg}^{-1}$ at day 49 and then decreases ultimately to $6.74 \mathrm{ng} \mathrm{mg}^{-1}$. Between day 16 and 49 the significant difference of $\mathrm{SP}_{\text {soil }}$ and $\mathrm{SP}_{\text {air }}$ eubacterial abundances disappeared and the population density of both variants converges to highest similarity at day 76 .

The sum of total measured DNA (DNA $\left.A_{\mathrm{tot}}=D N A_{E U B}+D N A_{F U N G}+D N A_{A R C H}\right)$ in $S_{\text {air }}$ is quantified to around $2 \mathrm{ng} \mathrm{mg}^{-1}$ until day 6 , increases to $13.61 \mathrm{ng} \mathrm{mg}^{-1}$ at day 49 and decreases again until $6.8 \mathrm{ng} \mathrm{mg}^{-1}$ at day $76 . \mathrm{SP}_{\text {soil }}$ increases from $2.38 \mathrm{ng} \mathrm{mg}^{-1}$ at the beginning to $19.64 \mathrm{ng}$ $\mathrm{mg}^{-1}$ at day 6 and then decreases to an endpoint of $11.39 \mathrm{ng} \mathrm{mg}^{-1}$. Except day 49 and 51 both variants show significant differences in DNA abundance, which is mainly due to fungal DNA.

Fungi population only emerged in $\mathrm{SP}_{\text {soil: }}$ Fungi (DNA $\mathrm{FunG}_{\mathrm{Fu}}$ ) show nearly no growth in $\mathrm{SP}_{\text {air }}$ and remain at DNA concentrations below $0.2 \mathrm{ng} \mathrm{mg}^{-1}$ for the whole experiment, whereas the fungal population of $\mathrm{SP}_{\text {soil }}$ grows from $1.11 \mathrm{ng} \mathrm{mg}^{-1}$ at day 0 to 5.56 at day 49 and ends at a value of $4.72 \mathrm{ng} \mathrm{mg}^{-1}$. Despite high standard deviations, through day 6 fungal populations of $\mathrm{SP}_{\text {soil }}$ and $\mathrm{SP}_{\text {air }}$ differ significantly.

Archaeal population is negligible: Archaeal $\left(\mathrm{DNA}_{\mathrm{ARCH}}\right)$ DNA amount is always $>0,002 \mathrm{ng}$ $\mathrm{mg}^{-1}$ and does not show significant differences between variants.

Eubacterial classes show significant differences between variants: With look on eubacterial classes, acidobacteria show a high standard deviation, but differ significantly between variants at days $6,16,51$ and 76. As $\mathrm{SP}_{\text {air }}$ does not exceed values of $0.25 \mathrm{ng} \mathrm{mg}$ ${ }^{1}$, DNA concentration in $\mathrm{SP}_{\text {soil }}$ growths from $0.44 \mathrm{ng} \mathrm{mg}^{-1}$ at day 0 to $3.36 \mathrm{ng} \mathrm{mg}^{-1}$ at day 16 and then stays between 2.19 an $3.22 \mathrm{ng} \mathrm{mg}^{-1}$. Actinobacteria in $\mathrm{SP}_{\text {air }}$ exhibit a nearly 
constant DNA concentration between 0.22 and $0.31 \mathrm{ng} \mathrm{mg}^{-1}$ until day 49, that does not exceed $0.52 \mathrm{ng} \mathrm{mg}^{-1}$ afterwards. In contrast, the $\mathrm{SP}_{\text {soil }}$ population rises from $0.33 \mathrm{ng} \mathrm{mg}^{-1}$ at the beginning to $1.65 \mathrm{ng} \mathrm{mg}^{-1}$ at day 6 and holds this value before decreasing to $0.95 \mathrm{ng}$ $\mathrm{mg}^{-1}$ between day 51 and day 76 . Although $\mathrm{SP}_{\text {soil }}$ shows an in tendency higher population, differences of both variants at days 51 and 76 are not significant. The development of $\mathrm{SP}_{\text {air }}$ $\alpha$-proteobacteria yielded in two plateaus: From day 0 to day 16 DNA concentration does not exceed $0.06 \mathrm{ng} \mathrm{mg}^{-1}$ and remains between 0.16 and $0.21 \mathrm{ng} \mathrm{mg}^{-1}$ from day 49 to day 76. The DNA concentration of $\mathrm{SP}_{\text {soil }}$ increases from $0.07 \mathrm{ng} \mathrm{mg}^{-1}$ at day 0 to 0.98 at day 6 and then decreases continuously to $0.39 \mathrm{ng} \mathrm{mg}^{-1}$. At day 51 and 76 there are no significant differences between variants.

Among the examined eubacterial classes, only $\beta$-Proteobacteria show a higher population in $\mathrm{SP}_{\text {air }}$ than in $\mathrm{SP}_{\text {soil: }}$ : Through day 16 the DNA concentration in $\mathrm{SP}_{\text {air }}$ remains smaller than $0.1 \mathrm{ng} \mathrm{mg}^{-1}$, but afterwards strongly increases to $9.22 \mathrm{ng} \mathrm{mg}^{-1}$ at day 49 followed by a decrease to $5.94 \mathrm{ng} \mathrm{mg}^{-1}$ at the end. However, in $\mathrm{SP}_{\text {soil }}$ DNA concentration rises from 0.22 $\mathrm{ng} \mathrm{mg}{ }^{-1}$ to $2.84 \mathrm{ng} \mathrm{mg}^{-1}$ until day 6 , amounts $1.92 \mathrm{ng} \mathrm{mg}^{-1}$ at day 16 and regulates itself to around $0.85 \mathrm{ng} \mathrm{mg}^{-1}$ for days 49 to 76 . Thereby, both variants differ significantly during the whole experiment.

325 Variants are dominated by strongly differing microbial classes: The percental relation of eubacterial class DNA to the total eubacterial DNA (Table 3) shows a dominance of acidobacterial DNA in $\mathrm{SP}_{\text {soil }}$ having ratios between $23.02 \%$ and $36.77 \%$ at days 49 to 76 , whereas values in $\mathrm{SP}_{\text {air }}$ remain smaller than $0.86 \%$. Also actinobacteria show a 3 -fold

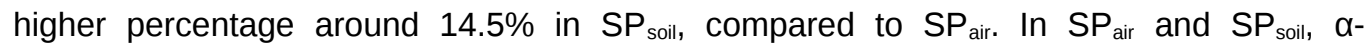
proteobacteria show percentages of $1.21 \%$ to $2.51 \%$ and $4.55 \%$ to $5.85 \%$, respectively, and therefore do not represent a dominant class. In strong contrast, $\beta$-Proteobacteria hold increasing percentages from $67.89 \%$ to $88.10 \%$ in $\mathrm{SP}_{\text {air }}$ compared to $8.67 \%$ to $12.27 \%$ in $\mathrm{SP}_{\text {soil. }}$ Cumulation show, that these classes cover $71.73 \%$ to $96.57 \%$ in $\mathrm{SP}_{\text {air }}$, mainly dominated by $\beta$-proteobacteria, and $51.88 \%$ to $69.12 \%$ in $\mathrm{SP}_{\text {soil. }}$ Cumulative values show an increasing percentage over time in both variants.

\subsection{Aggregate stability analysis}

The relative net SOC release $\mathrm{C}_{\text {rel }}=\mathrm{C}_{\text {frac }} \cdot \mathrm{C}_{\Sigma}^{-1}$, as defined as the ratio of the SOC release at the respective energy level $\left(\mathrm{C}_{\mathrm{frac}}\right)$ to the cumulative SOC release of all separated LFs plus the sediment $\left(\mathrm{C}_{\Sigma}\right)$, shows no differences between $\mathrm{SP}_{\text {soil }}$ and $\mathrm{SP}_{\text {air }}$, but between the two and $\mathrm{SP}_{\text {pure. }}$. Data are shown as mean values and standard deviations of 3 parallels (Fig. 3): 
SOIL Discuss., doi:10.5194/soil-2016-14, 2016

Manuscript under review for journal SOIL

Published: 7 March 2016

(c) Author(s) 2016. CC-BY 3.0 License.

$\mathrm{SP}_{\text {soil }}$ and $\mathrm{SP}_{\text {air }}$ do not differ in their relative $\mathrm{fFL}$ SOC release, which is around $4.6 \%$. In contrast, the fLF release of $\mathrm{SP}_{\text {pure }}$ amounts to $44.7 \%$.

However, $\mathrm{SP}_{\text {soil, }} \mathrm{SP}_{\text {air }}$ and $\mathrm{SP}_{\text {pure }}$ show differences of $\mathrm{SOC}$ release at $50 \mathrm{~J} \mathrm{ml}^{-1}$ : $\mathrm{SP}_{\text {soil }}$ releases $2.4 \%$ of its total particulate SOC in the $\mathrm{OLF}_{50}$, which is significantly less than the $\mathrm{A}_{\text {pure }} \mathrm{OLF}_{50}$ release of about $10.3 \%$. SP air lies in between having $6.3 \%$, without a significant difference to both.

At $500 \mathrm{~J} \mathrm{ml}^{-1}$, variants do not release different percentages of total particulate SOC. Whereas the oLF 500 detachment of $\mathrm{SP}_{\text {soil }}$ and $\mathrm{SP}_{\text {air }}$ are similar to each at $50 \mathrm{~J} \mathrm{ml}^{-1}, \mathrm{SP}_{\text {pure }}$ is reduced to $1.3 \%$. $\mathrm{SP}_{\text {air }}$ show a tendency to exceed $\mathrm{SP}_{\text {soil }}$ and $\mathrm{SP}_{\text {pure }}$.

The SOC content of each sediment fraction corresponds to the sum of the respective LF SOC release and is $92.3 \%$ in $\mathrm{SP}_{\text {soil }}, 83.9 \%$ in $\mathrm{SP}_{\text {air }}$ and 43.8 in $\mathrm{SP}_{\text {pure. }}$ Thus, only $\mathrm{SP}_{\text {pure }}$ shows a significantly reduced $\mathrm{SOC}$ content remaining in the soil matrix.

As in consequence $\mathrm{SP}_{\text {soil }}$ and $\mathrm{SP}_{\text {air }}$ do not differ significantly in any fraction (although in tendency $\mathrm{SP}_{\text {air }}$ releases more $\mathrm{SOC}$ than $\mathrm{SP}_{\text {soil }}$ in both occluded light fractions), $\mathrm{SP}_{\text {pure }}$ loses nearly half of its total particulate SOC in the fLF and additionally $10 \%$ after application of $50 \mathrm{~J} \mathrm{ml}^{-1}$.

The cumulative diagram of absolute $\mathrm{SOC}$ release (Fig. 4) identifies $\mathrm{SP}_{\text {soil }}$ as the sample releasing the smallest amount of SOC over all LFs. SP air has an in tendency increased SOC release, whereas $\mathrm{SP}_{\text {pure }}$ releases significantly more $\mathrm{SOC}$. The $\mathrm{SOC}$ release of $\mathrm{SP}_{\text {soil }}$ is identical to $A_{\text {pure, }}$ although its $\mathrm{SOC}$ content is 3.2-times higher due to biochar amendment. 


\section{Discussion}

Several studies demonstrated different compositions of EPS structural components in single- and multi-species laboratory cultures. These variations are dependent on species and incubation conditions. Most likely biofilms with fundamentally different microbial population structures would have different chemical composition and/or shape linking soil particles. Therefore we hypothesized that in a given soil a disparate development of the microbial community would cause a significant difference in aggregate stability. This hypothesis could be disproved for the given case and used best practice method, as strongly diverging microbial populations did not affect aggregate stability significantly.

Evaluation of data took place based on a period of stable bacterial development within the time span between day 49 and day 76: Showing a diverging development in the first 6 days, the amount of total eubacterial DNA in $\mathrm{SP}_{\text {soil }}$ und $\mathrm{SP}_{\text {air }}$ converge between day 6 and day 49 leading to similar $(p<0.05)$ quantities until the end of the experiment. Also, most of the observed eubacterial classes in both variants seem to be established until day 49 and show a stable or slightly decreasing population development in the final period from day 49 to day 76. (Fig. 1) These particular developments lead to a cumulative percental ratio of acidobacteria, actinobacteria, $\alpha$-proteobacteria and $\beta$-proteobacteria to total eubacterial

DNA, that increases from $71.7 \%$ to $96.6 \%$ in $\mathrm{SP}_{\text {air }}$ and from $51.9 \%$ to $69.1 \%$ in $\mathrm{SP}_{\text {soil }}$ between days 49 and 76 . Therefore this bundle of eubacterial classes hold the majority in both variants and become increasingly dominant. For these three reasons, the effect of named eubacterial populations as well as fungi and archaea on aggregate stability is discussed based on the final 28 days.

400 Although there is a similar total eubacterial DNA amount, population structure of examined eubacterial classes is strongly varying between variants within the final period: Acidobacteria and $\beta$-proteobacteria show a significant and actinobacteria an in tendency but not significant difference between variants, whereas $\alpha$-proteobacteria, which have low abundances $(<6 \%)$ in both variants, did not develop differently between $\mathrm{SP}_{\text {soil }}$ and $\mathrm{SP}_{\text {air. }}$. 405 Beside eubacteria, a fungal population developed in $\mathrm{SP}_{\text {soil, }}$ whose DNA spans $27.2 \%$ to $41.4 \%$ of the total measured population $\left(D N A_{\text {tot }}\right)$ in the final period, whereas only very small amounts of fungal DNA were found in $\mathrm{SP}_{\text {air }}$ samples. Thus, fungal glomalin and entanglement by fungal hyphae and filamentous bacteria (Aspiras et al., 1971; GasperiMago and Troeh, 1979; Tisdall, 1991; Bossuyt et al., 2001; Rillig et al., 2003) could 
population was found in both variants, which also have capability to build biofilms (Fröls, 2013). Thus, ecosystems of both variants were dominated by different taxa: During the final period acidobacteria, actinobacteria and fungi together hold $60.5 \%$ to $71.3 \%$ of the total measured DNA in $\mathrm{SP}_{\text {soil. }}$ In contrast, $\mathrm{SP}_{\text {air }}$ is nearly entirely dominated by $\beta$ proteobacteria, which provide $67.7 \%$ to $87.3 \%$ of the total measured DNA. We conclude, that in the final period both variants have strongly differing and each dominant microbial populations. This behavior implies a different development of EPS composition and biofilm structure. Based on our hypothesis, the different composition of microbial communities should have lead to a variation of aggregate stability between $\mathrm{SP}_{\text {soil }}$ and $\mathrm{SP}_{\text {air }}$.

Contrary to our forecast, in face of strongly differing microbial populations the incubated variants $\mathrm{SP}_{\text {soil }}$ and $\mathrm{SP}_{\text {air }}$ show no significant difference in aggregate stability in any fraction, although $\mathrm{SP}_{\text {soil }}$ has a tendency to release less SOC. Even considering a relation of microbial development and aggregate stability in single parallels, no correlation of the growth/decline of a specific taxon and soil aggregate stabilization/destabilization was observed (data not shown). However, an increase of aggregate stability during the incubation experiment was demonstrated comparing incubated variants and $\mathrm{SP}_{\text {pure: }}$ The significant decrease of the net relative SOC content within the fLFs of $\mathrm{SP}_{\text {soil }}$ and $\mathrm{SP}_{\text {air }}$ points to an occlusion of $\mathrm{POM}$ and therefore soil aggregate formation during the incubation.

The absolute $\mathrm{SOC}$ release of $\mathrm{SP}_{\text {soil }}$ and $\mathrm{SP}_{\text {air }}$ is in the magnitude of natural formed aggregates from the original soil $A_{\text {pure. }}$. That leads to the assumption, that the process of aggregation is at advanced stage after 76 days. Thus, breeding of stable soil aggregates in laboratory experiments is possible in short periods. Furthermore the absolute SOC release of both $\mathrm{SP}_{\text {soil }}$ and $\mathrm{A}_{\text {pure }}$ is identical, although their SOC content is $2.81 \%$ and $0.87 \%$, respectively. That indicates an extensive occlusion of biochar within the $\mathrm{SP}_{\text {soil }}$ matrix.

Following Büks and Kaupenjohann (in revision), biofilms play an important role in soil aggregate stabilization, whereas their microbial composition seems to be less relevant in this trial. What are the explanations?

First, relicts of the original EPS could endured drying, mechanical dispersion, y-sterilization and recolonization along the whole soil treatment and then dominate or precure EPS induced aggregate stability. This causation for similar stabilities of $\mathrm{SP}_{\text {soil }}$ and $\mathrm{SP}_{\text {air }}$ seems improbable due to y-degradation and metabolization (Kitamikado et al., 1990; Wasikiewicz et al., 2005), but could not be checked in this work.

More likely, the different microbial development in both incubated variants (1) causes only 
a little difference in EPS molecular composition, that is not sufficient to affect aggregate stability, or (2) the span of possible molecular EPS compositions has in general no significant influence on the mechanical characteristics of biofilms.

Also physical stabilization of soil particles by fungal hyphae and glomalin have no significant influence on aggregate stability in this work, given that - in addition to a similar eubacterial DNA amount in both variants - fungi represent $27 \%$ to $41 \%$ of the total measured DNA in $\mathrm{SP}_{\text {soil, }}$ but are nearly unrepresented in $\mathrm{SP}_{\text {air. }}$. However, the in tendency increased aggregate stability of $\mathrm{SP}_{\text {soil }}$ at 50 and $500 \mathrm{~J} \mathrm{ml}^{-1}$ compared to $\mathrm{SP}_{\text {air }}$ could underpin results of Molope et al. (1987) and Rillig (2004), that describe fungal hyphae and glomalin as factors of aggregate stability. A stabilizing effect of filamentous bacteria cannot be examined due to similar representation of Acidobacteria in both variants and no further investigation of phylogenetic diversity within this group.

Probably, but also not tested, similar aggregate stabilities in both variants can be caused by a multi-species balancing mechanisms, in which a loss of biofilm coherence due to a dominance of one group of taxa is compensated by another group.

Thus, our findings show that soil-microbial ecosystems with vastly different community structures can develop nearly similar aggregate stability. It implies that even the occupation of manifold niches by other taxa do not necessarily lead to a significant change in aggregate stability. Soil ecosystems could be able to compensate the influence of a population shift on EPS mechanical strength and aggregate coherence. Hence, biofilms as an agent of soil aggregate stability could be rather able to compensate the influence of agricultural practice on soil microbial community. However, retention of aggregate stability after population shifts do not imply a retention of other soil microbial processes e.g. metabolical characteristics.

Even so it remains an open question, whether the use of a more accurate - still not available - method of aggregate stability measurement could help to detect significant changes of aggregate stability, which are small but still have relevance for long term processes of SOC de-occlusion and soil erosion. 
SOIL Discuss., doi:10.5194/soil-2016-14, 2016

Manuscript under review for journal SOIL

Published: 7 March 2016

(c) Author(s) 2016. CC-BY 3.0 License.

\section{Conclusion}

Our hypothesis could not be affirmed. After 76 days of incubation, two variants of the same sandy agricultural soil (Su3) established a similar eubacterial abundance, but different community structures - one strongly dominated by $\beta$-proteobacteria, the other one by acidobacteria, actinobacteria and fungi, that represent an additional DNA amount. Strong structural differences between these microbial communities did not cause significant differences in aggregate stability. Given that influence of biofilms on aggregate stability was proved, differences in soil microbial composition do not necessarily affect aggregate stability. This leads to assume that soil aggregate stability could be resilient in face of agricultural practices, that change microbial community structure. Nonetheless this practices can affect other soil metabolic characteristics by changing the microbial population. Therefore, the condition of the soil microbial community should be included in agricultural practice.

In addition, the incubation experiment demonstrated the possibility to breed stable soil aggregates in the laboratory within 3 month.

\section{Author contribution}

The aggregate stability experiment was designed and carried out by F. Büks, the qPCR by P. Rebensburg. Data were evaluated by F. Büks with contributions from P. Lentzsch. The manuscript was prepared by F. Büks with contributions from M. Kaupenjohann. 


\section{Data availability}

Alaoui, A. et al., 2011, doi:10.1016/j.still.2011.06.002

Al-Halbouni, D. et al., 2009, doi:10.1016/j.watres.2008.10.008

Allison, D. G., 1998, URL: https://tspace.library.utoronto.ca/handle/1807/82

Aspiras, R. et al., 1971, URL: http://journals.Iww.com/soilsci/Citation/1971/...

Ayala-Hernández, I. et al., 2008, doi:10.1016/j.idairyj.2008.06.008

Baldock, J., 2002, doi:0-471-60790-8

Ball, B. and Robertson, E., 1994, doi:10.1016/0167-1987(94)90076-0

Barthes, B. and Roose, E., 2002, doi:10.1016/S0341-8162(01)00180-1

Baumgartl, T. and Horn, R., 1991, doi:10.1016/0167-1987(91)90088-F

Béjar, V. et al., 1998, doi:10.1016/S0168-1656(98)00024-8

Bengough, A. and Mullins, C., 1990, doi:10.1111/j.1365-2389.1990.tb00070.x

Bennie, A. and Burger, R. d. T., 1988, doi:10.1080/02571862.1988.10634239

Bossuyt, H. et al., 2001, doi:10.1016/S0929-1393(00)00116-5

Bronick, C. J. and Lal, R., 2005, doi:doi:10.1016/j.geoderma.2004.03.005

Büks, F. and Kaupenjohann, M., in revision, doi:10.5194/soil-2015-87

Celik, G. Y. et al., 2008, doi:10.1016/j.carbpol.2007.11.021

Chang, W.-S. et al., 2007, doi:10.1128/JB.00727-07

Costerton, J. W. et al., 1995, URL: http://www.annualreviews.org/doi/pdf/10.1146/...

Das, T. et al., 2014, doi:10.1371/journal.pone.0091935

Davey, M. E. and O'toole, G. A., 2000, doi:10.1128/MMBR.64.4.847-867.20

Fierer, N. et al., 2005, doi:10.1128/AEM.71.7.4117-4120.2

Flemming, H.-C. and Wingender, J., 2010, doi:10.1038/nrmicro2415

535 Fröls, S., 2013, doi:10.1042/BST20120304

Gasperi-Mago, R. R. and Troeh, F. R., 1979, doi:10.2136/sssaj1979.03615995004300040029x

Kaiser, M. and Berhe, A. A., 2014, doi:10.1002/jpln.201300339

Kitamikado, M. et al., 1990, URL: http://aem.asm.org/content/56/9/2939.short

540 Lane, D., 1991, URL: http://ci.nii.ac.jp/naid/10008470323/\#cit

Leigh, J. A. and Coplin, D. L., 1992, URL: http://www.annualreviews.org/doi/pdf/...

Lueders, T. and Friedrich, M. W., 2003, doi:10.1128/AEM.69.1.320-326.2003

Lützow, M. v. et al., 2006, doi:10.1111/j.1365-2389.2006.00809.x

Mah, T.-F. C. and O'Toole, G. A., 2001, doi:10.1016/S0966-842X(00)01913-2

Marty, N. et al., 1992, doi:10.1111/j.1574-6968.1992.tb05486.x 
Möhle, R. B. et al., 2007, doi:10.1002/bit.21448

Molope, M. et al., 1987, doi:10.1111/j.1365-2389.1987.tb02124.x

More, T. et al., 2014, doi:10.1016/j.jenvman.2014.05.010

Muyzer, G. et al., 1993, URL: http://socrates.acadiau.ca/isme/Symposium16/muyzer.PDF

Nunan, N. et al., 2003, doi:10.1016/S0168-6496(03)00027-8

Overmann, J. et al., 1999, doi:10.1007/s002030050744

Ozturk, S. and Aslim, B., 2010, doi:10.1007/s11356-009-0233-2

Pal, A. and Paul, A., 2008, doi:10.1007/s12088-008-0006-5

Ras, M. et al., 2011, doi:10.1016/j.watres.2010.11.021

Rillig, M. C., 2004, doi:10.4141/S04-003

Rillig, M. C. et al., 2003, doi:10.1016/S0038-0717(03)00185-8

Roberson, E. B. and Firestone, M. K., 1992, URL:

http://aem.asm.org/content/58/4/1284.short

Schmidt, M. et al., 1999, doi:10.1046/j.1365-2389.1999.00211.x

Schmitt, J. and Flemming, H.-C., 1999, doi:10.1016/S0273-1223(99)00153-5

Six, J. et al., 2002, doi:10.1023/A:1016125726789

Stach, J. E. et al., 2003, doi:10.1046/j.1462-2920.2003.00483.x

Steinberger, R. and Holden, P., 2005, doi:10.1128/AEM.71.9.5404-5410.2005

Taylor, H. and Brar, G., 1991, doi:10.1016/0167-1987(91)90080-H

Tisdall, J., 1991, doi:10.1071/SR9910729

Van Loosdrecht, M. et al., 2002, doi:10.1023/A:1020527020464

Votselko, S. et al., 1993, doi:10.1016/0167-7012(93)90016-B

Wasikiewicz, J. M. et al., 2005, doi:10.1016/j.radphyschem.2004.09.021

Weitere, M. et al., 2005, doi:10.1111/j.1462-2920.2005.00851.x

Zhang, X. et al., 1998, doi:10.1016/S0273-1223(98)00127-9

\section{Acknowledgement}

This project was financially supported by the Leibnitz-Gemeinschaft (SAW Pact for Research, SAW-2012-ATB-3). We are also grateful to our students Kathrein Fischer, Christine Hellerström, Annabelle Kallähne, Paula Nitsch, Susann-Elisabeth Schütze, Anne Timm and Karolin Woitke for pre-trials and soil preparation. 


\section{References}

Alaoui, A., Lipiec, J. and Gerke, H.: A review of the changes in the soil pore system due to soil deformation: A hydrodynamic perspective, Soil and Tillage Research, 115-116, 1--15, 2011.

Al-Halbouni, D., Dott, W. and Hollender, J.: Occurrence and composition of extracellular lipids and polysaccharides in a full-scale membrane bioreactor, water research, 43, 97-106, 2009.

Allison, D. G.: Exopolysaccharide production in bacterial biofilms, Biofilm Journal, 3, 1998.

Aspiras, R., Allen, O., Harris, R. and Chesters, G.: Aggregate stabilization by filamentous microorganisms., Soil Science, 112, 282--284, 1971.

Ayala-Hernández, I., Hassan, A., Goff, H., de Orduña, R. M. and Corredig, M.: Production, isolation and characterization of exopolysaccharides produced by Lactococcus lactis subsp. cremoris JFR1 and their interaction with milk proteins: Effect of $\mathrm{pH}$ and media composition, International dairy journal, 18, 1109--1118, 2008.

Baldock, J.: Interactions of organic materials and microorganisms with minerals in the stabilization of soil structure, in: Interactions between Soil Particles and Microorganisms Impact on the Terrestrial Ecosystem, 84--129, John Wiley \& Sons, Ltd: Chichester, West Sussex, UK, 2002.

Ball, B. and Robertson, E.: Effects of uniaxial compaction on aeration and structure of ploughed or direct drilled soils, Soil and Tillage research, 31, 135--148, 1994.

Barthes, B. and Roose, E.: Aggregate stability as an indicator of soil susceptibility to runoff and erosion; validation at several levels, Catena, 47, 133--149, 2002.

Baumgartl, T. and Horn, R.: Effect of aggregate stability on soil compaction, Soil and Tillage Research, 19, 203--213, 1991.

Béjar, V., Llamas, I., Calvo, C. and Quesada, E.: Characterization of exopolysaccharides produced by 19 halophilic strains of the species Halomonas eurihalina, Journal of biotechnology, 61, 135--141, 1998.

Bengough, A. and Mullins, C.: Mechanical impedance to root growth: a review of experimental techniques and root growth responses, Journal of soil science, 41, 341--358, 1990.

610 Bennie, A. and Burger, R. d. T.: Penetration resistance of fine sandy apedal soils as affected by relative bulk density, water content and texture, South African Journal of Plant and Soil, 5, 5--10, 1988.

Bossuyt, H., Denef, K., Six, J., Frey, S., Merckx, R. and Paustian, K.: Influence of microbial populations and residue quality on aggregate stability, Applied Soil Ecology, 16, 195--208, 2001. 
Bronick, C. J. and Lal, R.: Soil structure and management: a review, Geoderma, 124, 3-22, 2005.

Büks, F. and Kaupenjohann, M.: Enzymatic biofilm detachment causes a loss of aggregate stability in a sandy soil, Soil Journal, in revision.

Celik, G. Y., Aslim, B. and Beyatli, Y.: Characterization and production of the exopolysaccharide (EPS) from Pseudomonas aeruginosa G1 and Pseudomonas putida G12 strains, Carbohydrate polymers, 73, 178--182, 2008.

Chang, W.-S., van de Mortel, M., Nielsen, L., de Guzman, G. N., Li, X. and Halverson, L. J.: Alginate production by Pseudomonas putida creates a hydrated microenvironment and contributes to biofilm architecture and stress tolerance under water-limiting conditions, Journal of bacteriology, 189, 8290--8299, 2007.

Costerton, J. W., Lewandowski, Z., Caldwell, D. E., Korber, D. R. and Lappin-Scott, H. M.: Microbial biofilms, Annual Reviews in Microbiology, 49, 711--745, 1995.

Das, T., Sehar, S., Koop, L., Wong, Y. K., Ahmed, S., Siddiqui, K. S. and Manefield, M.: Influence of calcium in extracellular DNA mediated bacterial aggregation and biofilm formation, PloS one, 9, 2014.

Davey, M. E. and O'toole, G. A.: Microbial biofilms: from ecology to molecular genetics, Microbiol. Mol. Biol. Rev., 64, 847--867, 2000.

Fierer, N., Jackson, J. A., Vilgalys, R. and Jackson, R. B.: Assessment of soil microbial community structure by use of taxon-specific quantitative PCR assays, Appl. Environ. Microbiol., 71, 4117--4120, 2005.

Flemming, H.-C. and Wingender, J.: The biofilm matrix, Nat. Rev. Microbiol., 8, 623--633, 2010.

Fröls, S.: Archaeal biofilms: widespread and complex, Biochemical Society Transactions, 41, 393--398, 2013.

Gasperi-Mago, R. R. and Troeh, F. R.: Microbial effects on soil erodibility, Soil Science Society of America Journal, 43, 765--768, 1979.

Kaiser, M. and Berhe, A. A.: How does sonication affect the mineral and organic constituents of soil aggregates?_A review, J. Plant Nutr. Soil Sci., 177, 479--495, 2014.

Kitamikado, M., Yamaguchi, K., Tseng, C.-H. and Okabe, B.: Method designed to detect alginate-degrading bacteria, Applied and Environmental Microbiology, 56, 2939--2940, 1990.

Lane, D.: 16S/23S rRNA sequencing, Nucleic acid techniques in bacterial systematics, 125--175, 1991.

Leigh, J. A. and Coplin, D. L.: Exopolysaccharides in plant-bacterial interactions, Annual 
Lueders, T. and Friedrich, M. W.: Evaluation of PCR amplification bias by terminal restriction fragment length polymorphism analysis of small-subunit rRNA and mcrA genes by using defined template mixtures of methanogenic pure cultures and soil DNA extracts, Applied and Environmental Microbiology, 69, 320--326, 2003.

Lützow, M. v., Kögel-Knabner, I., Ekschmitt, K., Matzner, E., Guggenberger, G., Marschner, B. and Flessa, $\mathrm{H}$.: Stabilization of organic matter in temperate soils: mechanisms and their relevance under different soil conditions--a review, European Journal of Soil Science, 57, 426--445, 2006.

660 Mah, T.-F. C. and O'Toole, G. A.: Mechanisms of biofilm resistance to antimicrobial agents, Trends in microbiology, 9, 34--39, 2001.

Marty, N., Dournes, J.-L., Chabanon, G. and Montrozier, H.: Influence of nutrient media on the chemical composition of the exopolysaccharide from mucoid and non-mucoid Pseudomonas aeruginosa, FEMS microbiology letters, 98, 35--44, 1992.

Möhle, R. B., Langemann, T., Haesner, M., Augustin, W., Scholl, S., Neu, T. R., Hempel, D. C. and Horn, H.: Structure and shear strength of microbial biofilms as determined with confocal laser scanning microscopy and fluid dynamic gauging using a novel rotating disc biofilm reactor, Biotechnology and bioengineering, 98, 747--755, 2007.

Molope, M., Grieve, I. and Page, E.: Contributions by fungi and bacteria to aggregate stability of cultivated soils, Journal of Soil Science, 38, 71--77, 1987.

More, T., Yadav, J., Yan, S., Tyagi, R. and Surampalli, R.: Extracellular polymeric substances of bacteria and their potential environmental applications, Journal of environmental management, 144, 1--25, 2014.

Muyzer, G., De Waal, E. C. and Uitterlinden, A. G.: Profiling of complex microbial populations by denaturing gradient gel electrophoresis analysis of polymerase chain reaction-amplified genes coding for $16 \mathrm{~S}$ rRNA, Appl. Environ. Microbiol., 59, 695--700, 1993.

Nunan, N., Wu, K., Young, I. M., Crawford, J. W. and Ritz, K.: Spatial distribution of bacterial communities and their relationships with the micro-architecture of soil, FEMS 680 Microbiology Ecology, 44, 203--215, 2003.

Overmann, J., Coolen, M. J. and Tuschak, C.: Specific detection of different phylogenetic groups of chemocline bacteria based on PCR and denaturing gradient gel electrophoresis of 16S rRNA gene fragments, Arch. Microbiol., 172, 83--94, 1999.

Ozturk, S. and Aslim, B.: Modification of exopolysaccharide composition and production by three cyanobacterial isolates under salt stress, Environmental Science and Pollution Research, 17, 595--602, 2010.

Pal, A. and Paul, A.: Microbial extracellular polymeric substances: central elements in heavy metal bioremediation, Indian Journal of Microbiology, 48, 49--64, 2008. 
Ras, M., Lefebvre, D., Derlon, N., Paul, E. and Girbal-Neuhauser, E.: Extracellular polymeric substances diversity of biofilms grown under contrasted environmental conditions, Water research, 45, 1529--1538, 2011.

Rillig, M. C.: Arbuscular mycorrhizae, glomalin, and soil aggregation, Canadian Journal of Soil Science, 84, 355--363, 2004.

Rillig, M. C., Maestre, F. T. and Lamit, L. J.: Microsite differences in fungal hyphal length, glomalin, and soil aggregate stability in semiarid Mediterranean steppes, Soil Biology and Biochemistry, 35, 1257--1260, 2003.

Roberson, E. B. and Firestone, M. K.: Relationship between desiccation and exopolysaccharide production in a soil Pseudomonas sp., Applied and Environmental Microbiology, 58, 1284--1291, 1992.

Schmidt, M., Rumpel, C. and Kögel-Knabner: Evaluation of an ultrasonic dispersion procedure to isolate primary organomineral complexes from soils, European Journal of Soil Science, 50, 87--94, 1999.

Schmitt, J. and Flemming, H.-C.: Water binding in biofilms, Water science and technology, 39, 77--82, 1999.

Six, J., Conant, R., Paul, E. A. and Paustian, K.: Stabilization mechanisms of soil organic matter: implications for C-saturation of soils, Plant Soil, 241, 155--176, 2002.

Stach, J. E., Maldonado, L. A., Ward, A. C., Goodfellow, M. and Bull, A. T.: New primers for the class Actinobacteria: application to marine and terrestrial environments, Environ. Microbiol., 5, 828--841, 2003.

Steinberger, R. and Holden, P.: Extracellular DNA in single- and multiple-species unsaturated biofilms, Applied and environmental microbiology, 71, 5404--5410, 2005.

Taylor, H. and Brar, G.: Effect of soil compaction on root development, Soil and Tillage Research, 19, 111--119, 1991.

Tisdall, J.: Fungal hyphae and structural stability of soil, Soil Research, 29, 729--743, 1991.

Van Loosdrecht, M., Heijnen, J., Eberl, H., Kreft, J. and Picioreanu, C.: Mathematical modelling of biofilm structures, Antonie van Leeuwenhoek, 81, 245--256, 2002.

Votselko, S., Pirog, T., Malashenko, Y. R. and Grinberg, T.: A method for determining the mass-molecular composition of microbial exopolysaccharides, Journal of microbiological methods, 18, 349--356, 1993.

Wasikiewicz, J. M., Yoshii, F., Nagasawa, N., Wach, R. A. and Mitomo, H.: Degradation of chitosan and sodium alginate by gamma radiation, sonochemical and ultraviolet methods, Radiation Physics and Chemistry, 73, 287--295, 2005.

Weitere, M., Bergfeld, T., Rice, S. A., Matz, C. and Kjelleberg, S.: Grazing resistance of 
SOIL Discuss., doi:10.5194/soil-2016-14, 2016

Manuscript under review for journal SOIL

Published: 7 March 2016

(c) Author(s) 2016. CC-BY 3.0 License.

(c) (1)

725 Pseudomonas aeruginosa biofilms depends on type of protective mechanism, developmental stage and protozoan feeding mode, Environmental Microbiology, 7, 1593-1601, 2005.

Zhang, X., Bishop, P. L. and Kupferle, M. J.: Measurement of polysaccharides and proteins in biofilm extracellular polymers, Water science and technology, 37, 345--348, 1998.

730

735

740

745

750

755

760 
SOIL Discuss., doi:10.5194/soil-2016-14, 2016

Manuscript under review for journal SOIL

Published: 7 March 2016

(c) Author(s) 2016. CC-BY 3.0 License.

\section{Tables}

Table 1: Target classes and domains, appropriate primer pairs, annealing temperatures (AT) and standard organisms for qPCR. (AWl=Alfred Wegener Institute, Helmholtz Centre for Polar and Marine Research; DSM=German Collection of Microorganisms and Cell Cultures; ZALF=Leibniz Center for Agricultural Landscape Research)

\begin{tabular}{llll}
\hline Target organism & Primer pair & AT & Standard organism (origin) \\
\hline Archaea & Ar109f / Ar915r & $57^{\circ} \mathrm{C}$ & Methanosarcina mazei (AWI) \\
Acidobacteria & Acido31 / Eub518 & $50^{\circ} \mathrm{C}$ & Acidobacterium capsulatum (DSM11244) \\
Actinobacteria & Actino235 / Eub518 & $60^{\circ} \mathrm{C}$ & Streptomyces avermitis (DSM46492) \\
a-Proteobacteria & Eub338 / Alf685 & $60^{\circ} \mathrm{C}$ & Agrobacterium tumefaciens pGV2260 (ZALF) \\
B-Proteobacteria & Eub338 / Bet680 & $60^{\circ} \mathrm{C}$ & Burkholderia phymatum (DSM17167) \\
Eubacteria & Eub338 / Eub518 & $53^{\circ} \mathrm{C}$ & Pseudomonas putida F1 (ZALF) \\
Fungi & ITS1f / 5.8s & $52^{\circ} \mathrm{C}$ & Verticillium dahliae EP806 (ZALF) \\
\hline
\end{tabular}


SOIL Discuss., doi:10.5194/soil-2016-14, 2016

Manuscript under review for journal SOIL

Published: 7 March 2016

(c) Author(s) 2016. CC-BY 3.0 License.

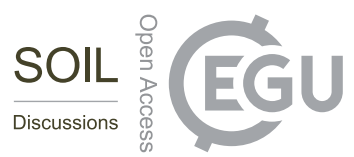

(c) (i)

Table 2: Applied primer sequences for class- and domain-specific qPCR.

\begin{tabular}{lll}
\hline Primer & Primer sequence & Reference \\
\hline 5.8s & 5'-CGCTGCGTTCTTCATCG-3' & (Fierer et al., 2005) \\
Acido31 & 5'-GATCCTGGCTCAGAATC-3' & (Fierer et al., 2005) \\
Actino235 & 5'-CGCGGCCTATCAGCTTGTTG-3' & (Stach et al., 2003) \\
Alf685 & 5'-TCTACGRATTTCACCYCTAC-3' & (Lane, 1991) \\
Ar109f & 5'-ACKGCTCAGTAACACGT-3' & (Lueders and Friedrich, 2003) \\
Ar915r & 5'-GTGCTCCCCCGCCAATTCCT-3' & (Lueders and Friedrich, 2003) \\
Bet680 & 5'-TCACTGCTACACGYG-3' & (Overmann et al., 1999) \\
Eub338 & 5'-ACTCCTACGGGAGGCAGCAG-3' & (Lane, 1991) \\
Eub518 & 5'-ATTACCGCGGCTGCTGG-3' & (Muyzer et al., 1993) \\
ITS1f & 5'-TCCGTAGGTGAACCTGCGG-3' & (Fierer et al., 2005)
\end{tabular}


SOIL Discuss., doi:10.5194/soil-2016-14, 2016

Manuscript under review for journal SOIL

Published: 7 March 2016

(c) Author(s) 2016. CC-BY 3.0 License.

Table 3: Measured eubacterial class DNA of $\mathrm{SP}_{\text {air }}$ and $\mathrm{SP}_{\text {soi }}$ variant in relation to total eubacterial DNA in percent at days 49 , 51 and 76.

\begin{tabular}{|c|c|c|c|c|c|c|}
\hline \multirow{2}{*}{$\begin{array}{l}\text { eubacterial class } \\
\text { at day }\end{array}$} & \multicolumn{3}{|c|}{$\mathrm{SP}_{\text {air }}$} & \multicolumn{3}{|c|}{$\mathrm{SP}_{\text {soil }}$} \\
\hline & 49 & 51 & 76 & 49 & 51 & 76 \\
\hline Acidobacteria & 0.47 & 0.79 & 0.86 & 23.02 & 32.69 & 36.77 \\
\hline Actinc & 2.16 & 5.97 & 5.51 & 14.42 & 14.94 & 14.23 \\
\hline$\alpha$-Proteobacteria & 1.2 & & 51 & .77 & .55 & 5.85 \\
\hline$\beta$-Proteobacteria & 67.89 & 79.75 & 88.10 & 8.67 & 8.83 & 12.27 \\
\hline sum & 71.73 & 88.88 & 96.57 & 51.88 & 60.88 & 69,12 \\
\hline
\end{tabular}


SOIL Discuss., doi:10.5194/soil-2016-14, 2016

Manuscript under review for journal SOIL

Published: 7 March 2016

(c) Author(s) 2016. CC-BY 3.0 License.

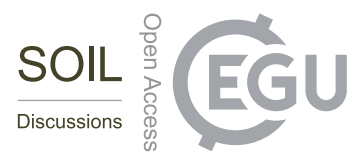

(c)

Figures

800

805

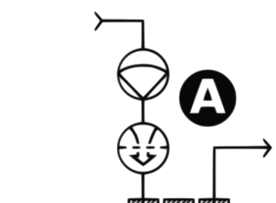

810

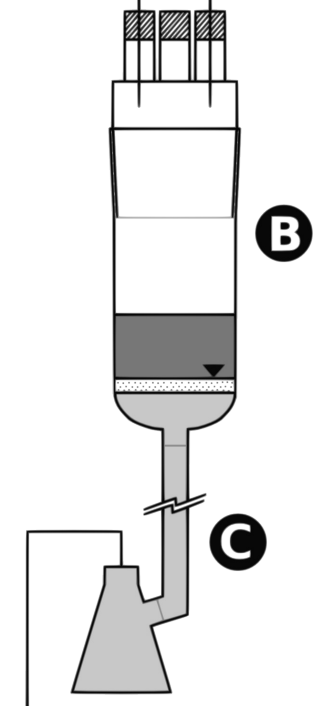

B

815

820
(D)

825

Fig. 1: Field capacity bioreactor with its components A) air supply composed of diaphragm pump and membrane filter, B) filter column with soil sample (dark grey) and filter plate (dotted), C) hydrostatic head (pale

835 grey) and D) liquid waste container. 
SOIL Discuss., doi:10.5194/soil-2016-14, 2016

Manuscript under review for journal SOIL

Published: 7 March 2016

(c) Author(s) 2016. CC-BY 3.0 License.
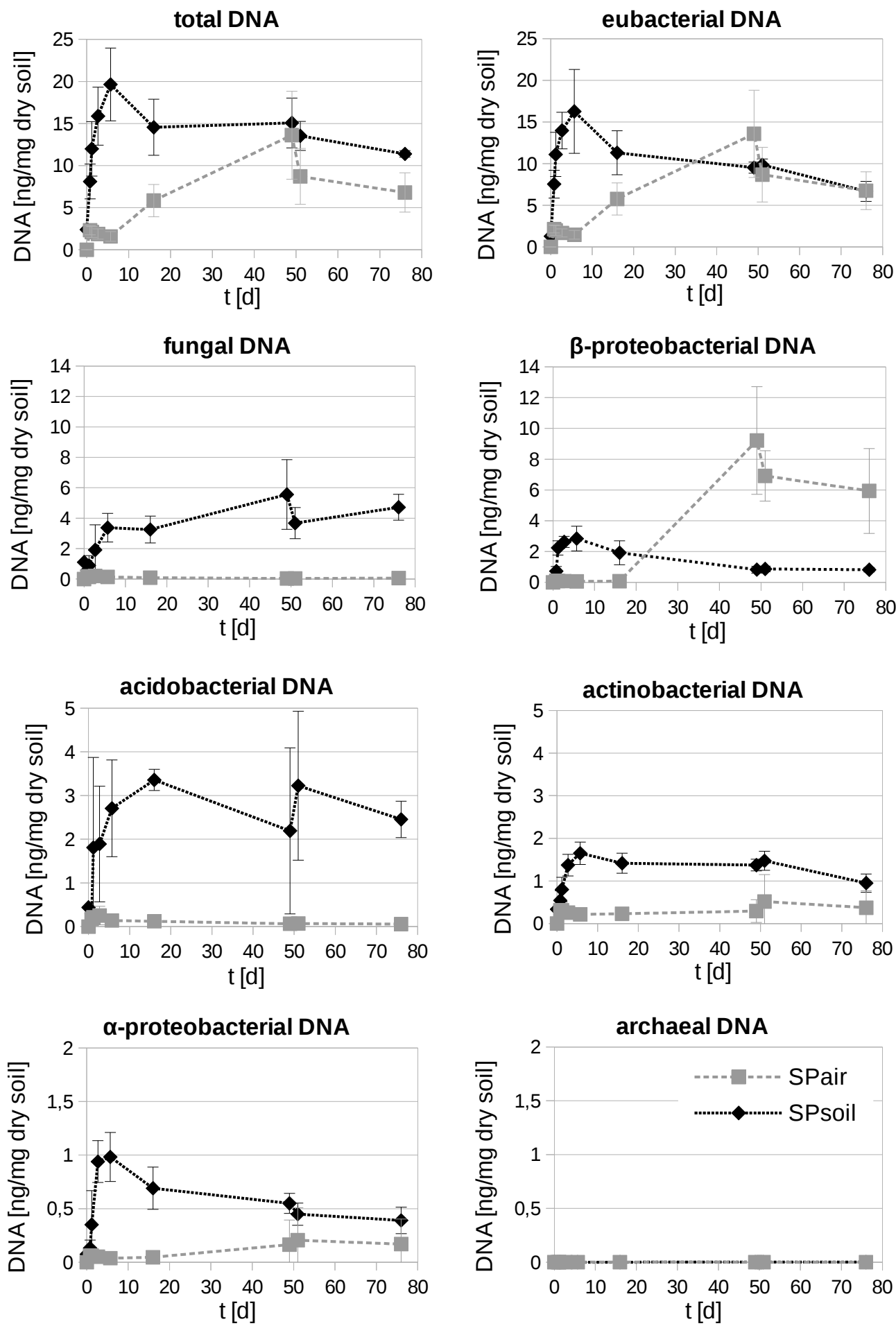

Fig. 2: DNA concentrations of phylogenetic classes and domains in soil with natural inoculate $\left(\mathrm{SP}_{\text {soil }}\right)$ and air-born infection $\left(\mathrm{SP}_{\text {air }}\right)$ (values in ng DNA per mg dry soil) 
SOIL Discuss., doi:10.5194/soil-2016-14, 2016

Manuscript under review for journal SOIL

Published: 7 March 2016

(c) Author(s) 2016. CC-BY 3.0 License.

850

\section{LF SOC release [\%Ctot]}

855

860

a $a \quad b$

$a$ ab b

a a $a$

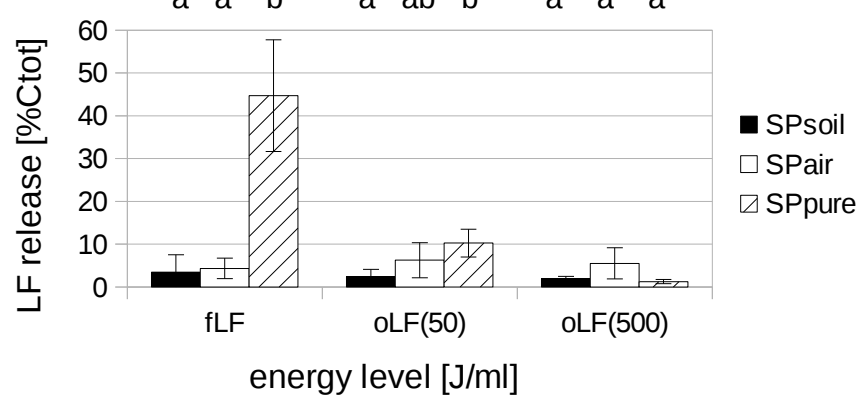

865

Fig. 3: Relative $\mathrm{SOC}$ release of variants $\left(\mathrm{SP}_{\text {soil }}, \mathrm{SP}_{\text {air }}, \mathrm{SP}_{\text {pure }}\right)$ at different energy levels $\left(0,50,500 \mathrm{~J} \mathrm{ml}^{-1}\right)$, illustrated by Tukey test characters $(a, a b, b)$.

870

875

880

885

890

895 
SOIL Discuss., doi:10.5194/soil-2016-14, 2016

Manuscript under review for journal SOIL

Published: 7 March 2016

(c) Author(s) 2016. CC-BY 3.0 License.

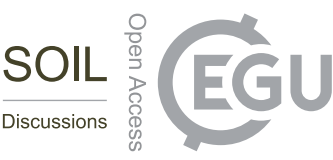

(c) (1)

cumulative LF SOC release $[\mathrm{mg} / \mathrm{g}]$

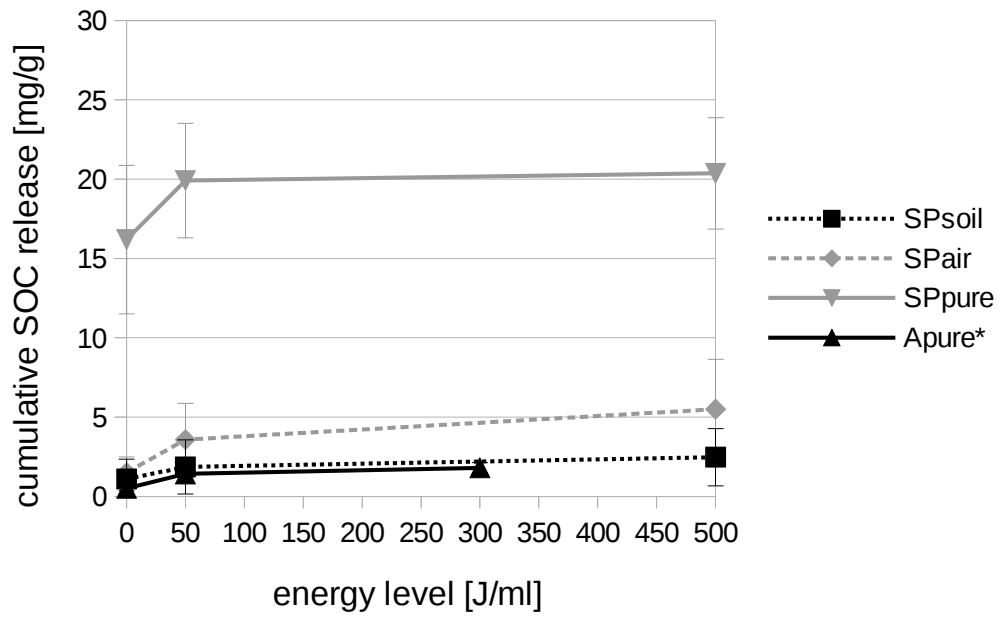

Fig. 4: Cumulative data of absolute SOC release (in $\mathrm{mg}$ SOC per g dry soil) of $\mathrm{SP}_{\text {soil, }}$, $\mathrm{SP}_{\text {air, }} \mathrm{SP}_{\text {pure }}$ and $\mathrm{A}_{\text {pure }}$ as a function of applied energy. ( $\left.{ }^{*}\right)$ marks $\mathrm{A}_{\text {pure }}$ as measured at 0 , 50 and $300 \mathrm{~J} \mathrm{ml}^{-1}$. 